\title{
Education Harmonization in Nursing and Social Work as Response to Vulnerable Patient/Client Groups in the new Candidate Member States - Solidarity from European Union (Note)
}

\author{
J. Otrubova (Jana Otrubova)1,2, D. Kalatova (Dagmar Kalatova)², A. Murgova \\ (Anna Murgova)', M. Katunska (Monika Katunska)², E. Zacharova \\ (Eva Zacharova)2, L. Matulnikova (Ludmila Matulnikova)2, M. Sramkova \\ (Maria Sramkova)2, L. Libova (Lubica Libova)2, J. Bydzovsky (Jan Bydzovsky)², \\ M. Jankechova (Monika Jankechova)², V. Kozon (Vlastimil Kozon)1,2, M. Olah \\ (Michal Olah)5 , H. Konosova (Helena Konosova)², M. Karvaj (Marian Karvaj)², \\ J. Benca (Juraj Benca)², R. Cauda (Roberto Cauda)33, A. Sabo (Anna Sabo)4, \\ P. Marks (Peter Marks) ${ }^{6}$
}

1 AKH Dept. of Nursing Vienna, Austria.

Original Article

2 St Lesley College, Nove Zamky, Institute of Nursing, Skalica, St. Dominic Institute Michalovce St. Sarah Institute Roznava and St. John Neumann Inst. Pribram, Czech Republic.

3 Inst of Infectious Diseases A Gemelli Univ. Hospital Univ. Cattolica Facolta di med e Chir, Rome, Italy.

${ }^{4}$ Martin Luther Inst. Backi Petrovac. Republic of Serbia.

5 I-GAP, Vienna, Austria.

${ }^{6}$ North London Postgrad Med School, London, UK.

\section{E-mail address:}

jana.otrubova@gmail.com

\section{Reprint address:}

Jana Otrubova

St. Lesley College and St. John Neumann Institute

Pribram

Czech Republic

Source: Clinical Social Work and Health Intervention Pages:

Volume: $10 \quad$ Issue: 4 Cited references: 2

\section{Reviewers:}

Johnson Nzau Mavole

Catholic university of Eastern Africa, Nairobi, Kenya

Jirina Kafkova

MSF, Freetown, Sierra Leone 


\section{Keywords:}

Health care. Education.

\section{Publisher:}

International Society of Applied Preventive Medicine i-gap

CSWHI 2019; 10(4): 63 - 66; DOI: 10.22359/cswhi_10_4_08 (c) 2019 Clinical Social Work and Health Intervention

\section{Abstract:}

According to the European Union (EU) Legislature within 10 years of association and full integration Central and Eastern European countries entering EU since 1998 have had to harmonize their university educational system; including the rules of education in nursing and social work due to the huge shortage of social and health care workers HCW. The second wave of enlargement happened after 2001 in South Eastern European region and the last is planned for 2020-2025. Newer member states such as SK CZ with old member countries such as AT, DE, IT and UK shall help to facilitate this harmonization process also for Serbia, Montenegro and Albania as soon as possible so that their nurses and social workers shall be integratable in EU labor Market.

\section{Introduction}

According to the European Union (EU) Legislature within 10 years of association and full integration Central and Eastern European countries entering EU since 1998 have had to harmonize their university educational system; including the rules of education in nursing and social work due to the huge shortage of social and health care workers HCW. The second wave of enlargement happened after 2001 in South Eastern European region and the last is planned for 2020-2025. Newer member states such as SK CZ with old member countries such as AT,DE,IT and UK shall help to facilitate this harmonization process also for Serbia, Montenegro and Albania as soon as possible, so that their nurses and social workers shall be integratable in EU labor Market. (1-2)

\section{Actual state of harmonization}

Equal levels of education among health care workers and social work specialists is mandatory to facilitate the labor market specially in the time of the rapid increase of elderly clients and patients in Scandinavia, UK and Western EU member states. The Bologna Magna Charta Universitarum, known as the Bologna Process may serve as one of the key documents as it is accepted by most old and new member states. However, inequities exist. Table 1 shows examples of both institutional and regional help and cooperation in Eastern Europe by current newer and also future member states in the process of negotiation (Montenegro, Northern Macedonia, Albania, Serbia). Unfortunately, another group of European countries including Moldova, Belarus and Ukraine are still in so called orphan status of this harmonization despite the labor market for social work specialists and nurses being 
urgently needed to facilitate this process. (1-2)

\section{Future challenges}

A functioning example may be adapted e.g. from Scandinavia and the UK where Sweden, Finland and the UK took over the patronage of the education system in Baltic region in former three USSR Republics (Estonia, Latvia, Lithuania) seconded by Poland. Another positive example is the interregional cooperation between Austria and Germany and Czech Slovak and Hungarian Universities, especially when many of them were founded by Monarchs from previous German or Austro Hungarian consortia without language barriers.

A third example is the support of Italy to Slovenia, Croatia and Montenegro. In addition, Poland and Hungary showed increasing activity within University cooperation in Ukraine, and Slovakia and Hungary in Serbia. However, Bosna and Herzegovina and Moldova are unfortunately still more and less abandoned looking for stronger alignment despite no or few language or political barriers existing. Surprisingly, more active approaches are seen in Georgia, Armenia and Azerbaijan to or from Turkish and USA Universities.

\section{Conclusions}

In conclusion, the need for social workers and nurses in the EU is huge but language, cultural, historic and educational barriers of many of the above mentioned countries play negative roles in labor market in health and social care. The result of this barrier and lack of harmonization with the Bologna Process and EU educational regulations, as well as previous political isolation are undoubtedly negative prognostic factors in the harmonization process. Little progress has been observed also due to the unwillingness to change the internal teaching and research environments in the Universities in Eastern Europe. The request for External Accreditation and Institutional evaluation to ENQUEA and other peer reviewing (accreditation) bodies from Eastern and Southern European Universities is not increasing (3). What shows is either too much respect for Western Universities (top 10 are from UK and FR and G. In the Top 100 there is only one from Eastern Central Europe). Probably it is more likely the unwillingness to change the totalitarian/communist style of working, teaching and research modes. These days we celebrate 30 years of the collapse of iron curtain and Berlin Wall. Those barriers were destroyed physically, however in many former Eastern European and Southern EU (Balkan) countries, still strongly persist in thinking, behavior and direction modes, in many (majority?) Universities in both new member state countries and even more in countries-in-process or countries-in-negotiation.

\section{References:}

1. WEST D (2016) East to West Universities cooperation: an examples within UoS and SK. J. Health Management 22.2016.33.

2. PERI HAJ ALI, SUBRAMANIAN S, SLADECKOVA V, BYDZOVSKY J, DURCOVA B, OLAH M, MATULNIKOVA L, KUBIK F, DOKTOROV V, BERESOVA A, FULA M (2019) Early detection of advance therapy reactions in orphans with AIDS. Acta Missiologica Vol.13, No. 2, p 84. 
Table l: Examples of functioning models of West-East and North-South cooperation in education in social work and nursing - Bologna Process implementation

\section{NORTH EAST}

Supporting Universities:

Finland, Sweden, UK

Supported Universities

Estonia, Lituania, Latvia,

WEST to EAST

Supporting Universities

Germany, Austria,

Supported Universities

Czech Rep, Slovakia, Slovenia, Hungary

SOUTH to EAST

Supporting Universities

Italy Switzerland

Supported Universities

Croatia, Montenegro, Albania Kosova

CENTRAL to EAST

Poland Slovakia Hungary

Supported Universities

Ukraine, Serbia

So called ORPHAN countries,

North Macedonia, Bosna and Herzegovina, Moldova 